Tuesday.-Reports and papers on pure and more chemical physics. Technical chemistry in $\mathrm{B}$.

Wednesday.-Arrears and papers on minor or semi-technical experimental details. Simultaneous sub-section, if necessary, for clearing off arrears without haste.

It may be felt that this means a hard week's work. Well, it does. Attendance at these meetings, if attentive, is no child's play. But if any diminution is necessary, I submit that it is better to shorten each day's sitting than to lessen the number of days. One is fresh enough at IO, when the committee work begins, but pretty tired and hungry at 3. If intercst dwindles, and papers begin to hurry themselves off without discussion, or to drone themselves dismally through, it is far better for the Section to rise at 2, instead of constraining itself to continue the process till the allotted hour. On the other hand, if interesting discussions arise, and attendance is good, it is very well to be able to continue the sitting till 3 or even longer. Though, indeed, Thursday is the only day on which a sitting may happily be continued beyond 3 without being disturbed by a committee meeting.

I have now said my say. I offer no apology for treating the subject, because my single aim in doing so has been to endeavour to do something to promote the usefulness and success of these meetings.

University College, Liverpool, September 13

\section{The Geological Age of the North Atlantic Ocean}

WhILE the interest attaching to Sir William Dawson's Presidential address at Birmingham is still fresh, I wish to be allowed to offer a few observations on that part of it which deals with the geological age of the North Atlantic Ocean. The President in referring to those writers who, like Mr. Crosby in America, Mr. Mellard Reade and myself in Britain, maintain that the North Atlantic and the American continent have in the main changed places in Palæozoic times, makes the following statement. Admicting the correctness of the facts as to the swelling out of the Palæozoic sediments in the direction of the Atlantic seaboard, he endeavours to account for these very striking phenomena thus : "I prefer, with Hall, to consider these belts of sediment as in the main the deposits of northern currents, and derived from Arctic land, and that, like the great banks of the American coast at the present day, which are being built up by the present Arctic current, they had little to do with any direct drainage from the adjacent shore." Now, in reading this passage it occurs to me that Sir W. Dawson must have felt he liad a very questionable case when he attempted to support it by such an hypothesis. To liken the great sheets of sediment which spread themselves sometimes over half the North American continent south of the Great Lakes to the banks heaped up along the Atlantic coast is a point of analogy in which, probably, he will find few to concur. The Palæozoic sediments are certainly not banks, but sheets originally spread over the sea-bed, and distributed according to certain recognised laws of increase and decrease of thickness.

But, putting this point aside, I may be allowed to ask, How can we suppose the existence of a northern current bringing sediment from the Arctic regions, and spreading it over Eastern America, unless there was at the same time a coast-line to guide the current in taking a southerly direction; and if such a coastline existed, must it not have lain along the eastern American shore, becanse the American continent itself was then sub merged? If we examine a current-chart of the globe, we find that all the N.-S. oceanic currents flow along the continental shores and take their directions from them. If America and the Atlantic, south of the Arctic regions, were both oceanic in Palæozoic times, then the current would not have been southerly, but westerly or easterly, according to circumstances, certainly not flowing from north to south; therefore this explanation for the distribution of the Palæozoic strata cannot, I venture to say, bear the test of examination.

Again, the President states: "It is further obvious that the ordinary reasoning respecting the necessity of continental areas. in the present ocean basins would actually oblige us to suppose that the whole of the oceans and continents had repeatedly changed places." Now, as regards the North Atlantic, this is an objection which is purely imaginary; because the evidence goes to show that it remained in the condition of a continent all through the Palæozoic ages, with, of course, ever-varying margins; and it is only so far (as a writer in the Athencum, Sep- tember 4 , has properly pointed out) that I have argued in favour of its continental condition. But undoubtedly the arguments in favour of the interchange of ocean and continent during Palæozoic times, as applicable to North America, would be found to apply more or less strictly to other oceans and continents, owing to the wide distribution of the formations of this period over the present continental areas. Northern and Central Africa and Greenland may prove exceptions; but apart from these tracts, Palæozoic strata appear to have been distributed (prior to denudation) over by far the greater portions of the continents, and the sediments must have been derived from the adjoining continental areas, which are now covered by the waters of the ocean.

The question between the President and myself is mainly this: Did the sedimentary strata of the Palæozoic period of North America come from lands lying around the Arctic Circle, or from others occupying the position of the North Atlantic? American geologists have a favourite theory that the Arctic regions have been the originating lands, but I venture to repeat that if it be allowed as a general principle that the originating lands lay in the direction towards which the sedimentsthicken, and opposite to that in which the limestones are most developed, the conclusion is inevitable that the Atlantic was in the main a landsurface in Palæozoic times. All the Palæozoic formations of North America point to this conclusion, as I have on former occasions attempted to show, ${ }^{1}$ and this, regardless of the question whether or not there was also land along the Arctic Circle. Throughout the Silurian, Devonian, and Carboniferous epochs marine limestones were in course of formation mainly over the regions west of the Mississippi, and sediments mainly east of that line and chiefly in the Appalachian region. The general direction of the swelling out of the sediment is (if I mistake not) rather south of east than north of east. Thus, the "Potsdam beds" appear to swell out towards the E.S.E.; the "Hudson beds," S.E., and S.S.E. ; the "Hamilton beds" of the Devonian, towards the E. or E.S.E. ; and different members of the Carboniferous series swell out N.E., E., and S.E. On the whole, and as a general result, the centre from which the sediments appear to have been chiefly distributed seems to have lain around the point intersected by the parallel $30^{\circ} \mathrm{N}$. lat. and the meridian of $60^{\circ} \mathrm{W}$. long., except in the Carboniferous period, when the originating lands appear to have lain in the region of the first Atlantic cable, between Newfoundland and the British Isles, and which lands were probably continuous with those of the Arctic continent.

I wish, in conclusion, to take this opportunity of adding a few words in reference to the Archæan rocks. I am much disposed to concur in the view of Sir W. Dawson-that the fundamental gneissose beds of the Archæan period may have had a different origin from the metamorphic strata of succeeding periods, and that they may not have been originally sediments. This observation does not, however, apply to the schists, limestones, and quartzites which succeed them, and which sometimes include beds of gneiss, as in Scandinavia. From this point of view, the birthday of the Atlantic continent may not have dated farther back than the commencement of the Palæozoic age-represented in Britain by the Cambrian, and in America by the Potsdam, sandstone. As a continent it remained till the close of that age. To what extent it survived the terrestrial movements which closed that epoch I am not prepared to say.

Dublin, September 15

\section{EDWARd Hull}

\section{Earthquake at Sea}

Captain H. J. Olsen, commanding the brig Wilhelmine of Drammen, reports that, on the Ist inst., being by dead reckoning in lat. $50^{\circ} \mathrm{Io}^{\prime} \mathrm{N}$., long. $\mathrm{I}^{\circ} 4 \mathrm{O}^{\prime} \mathrm{W}$., he observed, between 3.30 and 4 p.m., three rumblings at short intervals, during which the ship was felt to tremble violently, so that both the bulwarks of the cabin and plates on the table clattered. The wind was north-west, with a gentle breeze, and the ship was on the starboard tack.

Det Norske Meteorologiske Institut, Christiania, September 15

\section{Peripatus}

NAture for July 29 (p. 288) mentions that Peripatus has been taken at Demerara. It may interest some of the readers of "Scient. Trans. Roy. Dublin Soc., vol. iii. 2 ser. p., 305 (1885), and 